\title{
KEMAMPUAN VISUAL-SPATIAL THINKING DALAM GEOMETRI RUANG MAHASISWA UNIVERSITAS KUNINGAN \\ Sumarni ${ }^{1)}$ dan Anggar Titis Prayitno ${ }^{2)}$
}

Program Studi Pendidikan Matematika Universitas Kuningan Jalan Cut Nyak Dhien

No. 36 Cijoho Kuningan Jawa Barat

$\underline{\text { marnie1205@gmail.com }}^{1}{ }^{\text {; }}$ medodinejma@ gmail.com $^{2)}$

\begin{abstract}
Abstrak
Geometri adalah salah satu cabang matematika yang diajarkan di bangku sekolah, dari sekolah dasar, sekolah menengah hingga perguruan tinggi.mahasiswa Program Studi Pendidikan Matematika Universitas Kuningan dalam mata kuliah Geometri Ruang, yang memperoleh prestasi kurang memuaskan dalam mata kuliah geometri ruang. Kemampuan berpikir visual (visual thinking) dan berpikir spasial (spatial thinking) mempengaruhi prestasi peserta didik dalam belajar geometri ruang. Penulis tertarik untuk melakukan diagnosis kesulitan mahasiswa Program Studi Pendidikan Matematika Universitas Kuningan dalam mata kuliah Geometri Ruang melalui Tes Kemampuan Visual-Spatial Thinking. Tujuan penelitian ini adalah mendiagnosis kemampuan visual-spatial thinking Mahasiswa Universitas Kuningan dan mendeskripsikan upaya untuk meningkatkan hasil belajar mahasiswa dalam mata kuliah geometri ruang. Berdasarkan pemaparan hasil pengerjaan soal kemampuan visual-spatial thinking dan pembahasan maka dapat disimpulkan bahwa: a) Kemampuan visual-spatial thinking mahasiswa prodi pendidikan matematika Universitas Kuningan masih rendah, terutama mahasiswa yang berkemampuan sedang dan rendah. Mahasiwa masih mengalami kesulitan dalam menyelesaikan soal yang berkaitan dengan konsep garis tegak lurus dan proyeksi; jarak titik, garis dan bidang; serta sudut antara garis dan bidang; b) Kemampuan visual-spatial thinking merupakan kemampuan yang harus dikembangkan dalam belajar geometri ruang, salah satu penyebab rendahnya hasil belajar geometri ruang adalah karena kemampuan visual-spatial thinking yang masih rendah; c) Salah satu upaya meningkatkan kemampuan visual-spatial thinking mahasiswa adalah pembelajaran geometri ruang melalui pembelajaran berbasis masalah dengan berbantuan software GeoGebra.
\end{abstract}

Kata Kunci: Kemampuan Visual-Spatial Thinking, Geometri Ruang

\section{Abstract}

Geometry is a branch of mathematics that is taught in school, from elementary school, high school and college. Student Mathematics Education Kuningan University in the course Geometry $3 D$ which gained less than satisfactory 
achievements in the course of the geometry 3D. The ability visual thinking and spatial thinking affect learners' achievements in learning the geometry. Authors interested in diagnosing the difficulties Student Mathematics Education of Kuningan University in the course Geometry 3D through Ability Test of Visual-Spatial Thinking. The purpose of this study is to diagnose visual-spatial thinking abilities Student of Kuningan University and describe efforts to improve student results in the course of the geometry 3D. Based on the exposure of the work about the ability of visual-spatial thinking and discussion it can be concluded that: a) The ability of visual-spatial thinking mathematics education student Kuningan University is still low, especially students who are capable of moderate and low. Students are still experiencing difficulties in resolving problems related to the concept of a perpendicular line and projections; distance of points, lines and areas; as well as the angle between the line and the field; $b$ ) The ability of visual-spatial thinking is a skill that must be developed in studying the geometry $3 D$, one of the low result of learning the geometry $3 D$ is due to the ability of visual-spatial thinking is still low; c) One effort to improve visual-spatial thinking ability of students is learning the geometry of space through problem-based learning with assisted software GeoGebra.

Keywords: Visual-Spatial Thinking Ability, Geometri 3D

\section{A. Pendahuluan}

Geometri adalah salah satu cabang matematika yang diajarkan di bangku sekolah, dari sekolah dasar, sekolah menengah hingga perguruan tinggi. Geometri juga merupakan bidang penting dari matematika. Geometri merupakan sebuah konsep yang menghubungkan berbagai bidang dalam matematika (Schwartz, 2010). Geomerti dalam hal ini geometri ruang juga merupakan mata kuliah yang diajarkan di Program Studi Pendidikan Matematika Universitas Kuningan.

Berdasarkan sudut pandang psikologi, geometri merupakan penyajian abstraksi dari pengalaman visual dan spasial, misalnya bidang, pola, pengukuran, dan pemetaan (Risnawati, 2012). Sedangkan dari sudut matematika, geometri menyediakan pendekatan-pendekatan untuk pemecahan masalah, misalnya: gambar-gambar, diagram, sistem koordinat, vektor, dan transformasi. Setelah melaksanakan pembelajaran geometri, peserta didik harus mempunyai 4 kemampuan yaitu: (1) menganalisis karakteristik dan sifatsifat bentuk geometri dua dan tiga dimensi dan mengembangkan argumen-argumen matematika tentang hubungan geometri itu; menetapkan lokasi dan menjelaskan hubungan spasial menggunakan koordinat geometri dan sistem representasi lainnya; (3) memakai transformasi dan menggunakan simetri untuk menganalisis situasi matematika; (4) menggunakan visualisasi, penalaran spasial, dan model geometri untuk memecahkan 
masalah (National Academy Science, 2006).

Kenyataan yang terjadi di lapangan tidak sejalan dengan harapan. Peserta didik mengalami kesulitan untuk menyelesaikan soal geometri. Geometri dianggap sebagai bidang kajian matematika yang sulit. Kariadinata (2010) mengemukakan bahwa banyak persoalan geometri yang sulit diselesaikan dan pada umumnya dalam mengkonstruksi bangun ruang geometri. Sudarman (Abdussakir, 2009) menemukan masih banyak peserta didik yang mengalami kesulitan belajar geometri, dari tingkat SD hingga perguruan tinggi. Gumilar (2012) menyatakan hal yang serupa bahwa masih banyak peserta didik yang mengalami kesulitan dalam memahami geometri, terutama geometri ruang yang merupakan materi matematika yang tidak disukai oleh peserta didik. Hal yang sama juga dialami oleh mahasiswa Program Studi Pendidikan Matematika Universitas Kuningan dalam mata kuliah Geometri Ruang, yang memperoleh prestasi kurang memuaskan dalam mata kuliah geometri ruang.

Geometri memiliki keabstrakan objek, sehingga menuntut peserta didik untuk mampu membayangkan hal-hal yang tidak jelas bentuk fisiknya (tidak nyata). Berdasarkan penjelasan tersebut, kemampuan visualisasi dan spasial adalah kemampuan yang harus dimiliki oleh peserta didik dalam pembelajaran geomerti. "Visual imagination seems to play an important role in extending geometrical knowledge" (Giaquinto, 2007) Artinya imajinasi visual memiliki peran penting dalam memperluas pengetahuan geometri. Terdapat tiga cara berpikir, yaitu: berpikir audio (audiotory thinking), berpikir visual (visual thinking), dan berpikir kinestetik (kinesthetic thinking). Visualisasi merupakan bagian dari berpikir visual (visual thinking) (Sword, 2005).

Visual thinking memegang peran penting dalam keberhasilan pembelajaran geometri sebab peserta didik yang belajar tanpa menggunakan kemampuan visual thinking rawan mengalami miskonsepsi, kemampuan visual thinking berperan untuk memecahkan masalah dari soal-soal yang membutuhkan penalaran tingkat tinggi (Ismi \& Hidayatulloh, 2011). Jika kemampuan untuk memecahkan masalah adalah jantung dari matematika, maka visualisasi merupakan inti pemecahan masalah matematika dalam pembelajaran geometri.

Selain kemampuan visual thinking, kemampuan spasial juga dibutuhkan dalam mempelajari geometri. Kemampuan spasial adalah suatu kemampuan dalam merepresentasikan, mentransformasi, membangun, dan memanggil kembali informasi simbolik tidak dalam bentuk bahasa (Black, 2005). Kemampuan spasial dengan nyata sangat dibutuhkan pada ilmu-ilmu teknik dan 
matematika, khususnya geometri (Nemeth, 2007). Kemampuan visualisasi spasial merupakan tahap awal dalam berpikir spasial (spatial thinking) (Dwirahayu, 2013). Dari hal ini terlihat bahwa induk dari kemampuan spasial adalah kemampuan berpikir spasial/spatial thinking. Spatial thinking merupakan bagian dari berpikir geometri. Lebih lanjut Dwirahayu (2013) menyatakan bahwa spatial thinking dipengaruhi oleh pengembangan kemampuan visualisasi. Artinya, kemampuan visualisasi merupakan salah satu kemampuan dasar dalam spatial thinking yang mendukung pada pemahaman konsep matematika, khususnya pada bidang kajian geometri.

\section{Berdasarkan pemaparan} tersebut dapat ditarik kesimpulan bahwa ada kaitan yang erat antara berpikir visual (visual thinking) dan berpikir spasial (spatial thinking). Keduanya sama-sama sangat penting dalam pembelajaran geometri. Penulis berasumsi bahwa kedua kemampuan berpikir tersebut yaitu berpikir visual (visual thinking) dan berpikir spasial (spatial thinking) mempengaruhi prestasi peserta didik dalam belajar geometri ruang. Sehingga, penulis tertarik untuk melakukan diagnosis kesulitan mahasiswa Program Studi Pendidikan Matematika Universitas Kuningan dalam mata kuliah Geometri Ruang melalui Tes Kemampuan Visual-Spatial Thinking. Tujuan penelitian ini adalah mendiagnosis kemampuan visual-spatial thinking Mahasiswa Universitas Kuningan dan mendeskripsikan upaya untuk meningkatkan hasil belajar mahasiswa dalam mata kuliah geometri ruang.

\section{B. Landasan Teori}

1. Kemampuan Visual-Spatial Thinking

\section{a. Visual Thinking}

Berpikir mendasari hampir semua kegiatan manusia. Terdapat tiga cara berpikir, yaitu: berpikir audio (audiotory thinking), berpikir visual (visual thinking), dan berpikir kinestetik (kinesthetic thinking) (Sword, 2005). Menurut Brasseur (Surya, 2011) Visual thinking atau berpikir visual adalah proses intelektual intuitif dan ide imajinas visual, baik dalam pencitraan mental maupun gambar. 


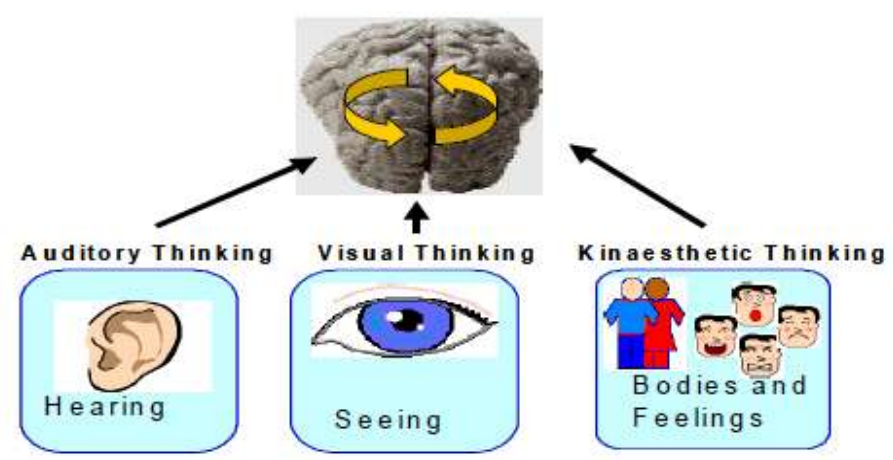

The $3 \mathrm{~m}$ ain ways of thinking correspond with how ourbrain processes our basic senses-eyes, ears, bodies and feelings.

(C) 2005 Lesley K Sword

\section{Gambar 1 Tiga Cara Berpikir (Sword, 2005)}

\section{Zhukovskiy dan Pivovarov} (2008) menyatakan bahwa visual thinking merupakan tipe pemikiran nonverbal dan telah diteliti secara luas oleh parapsikolog. Para psikolog percaya bahwa fungsi utama visual thinking ialah untuk mengkoordinasi makna berbeda dari suatu gambaranmenjadi gambar visibel yang utuh. Lebih lanjut Zhukovskiy dan Pivovarov (2008), menyatakan bahwa visual thinking merupakan aktivitas seseorang yang menghasilkan gambaran baru danbentuk visual baru. Bentuk-bentuk ini menjadikan makna konsep yang abstrakmenjadi kelihatan/visible.

Visual thinking adalah suatu proses memformulasikan dan mengaitkan ide-ideserta menemukan pola-pola baru yang muncul (Bolton, 2011). Visual thinking merupakan proses iterasi yang menggunakan model tiruan dan sketsa-sketsa untuk membantu mengembangkan ide dan gagasan baik secara kuantitatif ataupun kualitatif. Sehingga menurut
Bolton (2011) langkah-langkah visual thinking adalah:

1) Looking;pada tahap ini, peserta didik mengidentifikasi masalah dan hubungan timbal baliknya,merupakan aktivitas melihat dan mengumpulkan.

2) Seeing; mengerti masalahdan kesempatan, dengan aktivitas menyeleksi dan mengelompokkan.

3) Imagining; mengeneralisasikan langkah untuk menemukan solusi, kegiatanpengenalan pola.

4) Showing and telling; menjelaskan apa yang dilihat dandiperoleh kemudian mengkomunikasikannya.

\section{b. Spatial Thinking}

Spatial thinking merupakan salah satu jenis berpikir matematis yang banyak melibatkan kemampuan penalaran dan kemampuan koneksi yang berhubungan dengan keruangan (dimensi 3). Spatial thinking didefinisikan oleh National Academy Science (2006) sebagai kumpulan kemampuan kognitif: pengetahuan deklarasi (pernyataan) dan persepsi serta beberapa operasi kognitif yang 
digunakan yakni mentransformasi, mengkombinasi, atau mengoperasi pengetahuan dalam konteks dimensi ruang, sedangkan Watson dan Crick (National Academy Science, 2006) mendefinisikan spatial thinking sebagai salah satu model berpikir yang mengunakan konteks yang beragam dengan tingkat kesulitan yang berbeda.

Menurut National Academy Science (2006) ada tiga langkah komponen berpikir spasial (spatial thinking) itu sendiri yaitu:

1) Penggalian struktur spasial: proses ini melibatkan deskripsi pola hubungan antara identifikasi representasi spasial dan pemahaman mengenai pola tersebut. Dengan kata lain, membayangkan posisi suatu obyek.

2) Transformasi spasial: translasi dalam ruang atau transformasi skala lebih mudah daripada rotasi atau perubahan perspektif.

3) Menggambar: langkah ini adalah yang paling tersulit sekaligus terpenting. Merepresentasi dan mengkonstruksi model yang berkaitan dengan suatu obyek dalam gambar.

\section{c. Visual-Spatial Thinking}

Mohler (2010) mengemukakan dalam visual-spatial thinking memerlukan: (1) pengenalan atau pengidentifikasian visual; pencocokan pola, baik $2 \mathrm{D}$ maupun 3D; (3) berpikir dan memanipulasi informasi, baik 2D maupun 3D;
(4) representasi mental; (5) rotasi dan transformasi; (6) orientasi atau reorientasi.

1. Kemudian lebih lanjut Mohler (2010) mendeskripsikan sistem visualspatial. Berikut merupakan sistem dari visual-spatial:

Berdasarkan pemaparan di atas dapat ditarik kesimpulan bahwa ada kaitan yang erat antara berpikir visual (visual thinking) dan berpikir spasial (spatial thinking). Keduanya samasama sangat penting dalam pembelajaran geometri. Penulis dalam penelitian menggabungkan kedua kemampuan berpikir ini menjadi kemampuan visual-spatial thinking. Dengan mengkaji teori dari dua kemampuan berpikir tersebut penulis berkesimpulan bahwa kemampuan visual-spatial thinking adalah kemampuan untuk mengubah informasi menjadi objek geometri; membayangkan posisi suatu objek geometri sesudah objek tersebut mengalami rotasi, refleksi, atau dilatasi; membandingkan kaitan hubungan logis dari unsur-unsur suatu bangun ruang; menduga secara akurat bentuk suatu objek dipandang dari sudut pandang tertentu; menentukan objek yang cocok pada posisi tertentu dari sederetan objek bangun geometri ruang atau mengenal pola; merepresentasikan model-model bangun geometri yang digambarkan pada bidang datar; menemukan informasi dari visual berupa objek sederhana dalam konteks keruangan yang kompleks. 


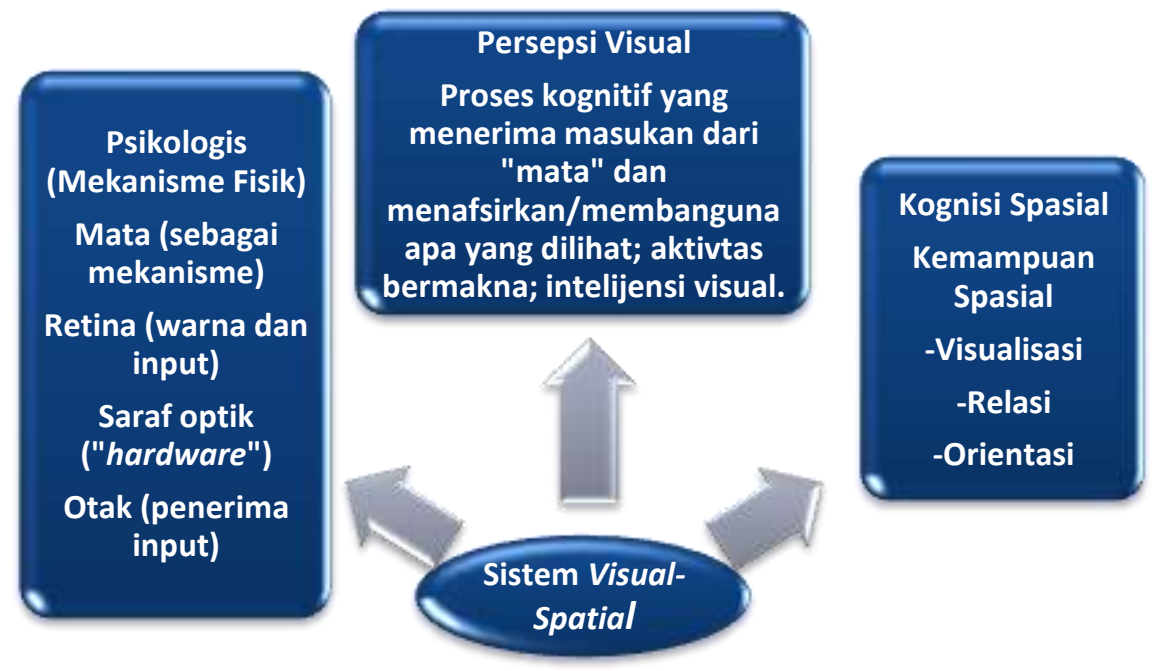

Gambar 2.2 Sistem Visual-Spatial

Berdasarkan pemaparan di atas dapat ditarik kesimpulan bahwa ada kaitan yang erat antara berpikir visual (visual thinking) dan berpikir spasial (spatial thinking). Keduanya samasama sangat penting dalam pembelajaran geometri. Penulis dalam penelitian menggabungkan kedua kemampuan berpikir ini menjadi kemampuan visual-spatial thinking. Dengan mengkaji teori dari dua kemampuan berpikir tersebut penulis berkesimpulan bahwa kemampuan visual-spatial thinking adalah kemampuan untuk mengubah informasi menjadi objek geometri; membayangkan posisi suatu objek geometri sesudah objek tersebut mengalami rotasi, refleksi, atau dilatasi; membandingkan kaitan hubungan logis dari unsur-unsur suatu bangun ruang; menduga secara akurat bentuk suatu objek dipandang dari sudut pandang tertentu; menentukan objek yang cocok pada posisi tertentu dari sederetan objek bangun geometri ruang atau mengenal pola; merepresentasikan model-model bangun geometri yang digambarkan pada bidang datar; menemukan informasi dari visual berupa objek sederhana dalam konteks keruangan yang kompleks.

\section{Metodologi \\ 1. Metode Peneltian}

Metode penelitian yang digunakan adalah penelitian kualitatif. Karakteristik penelitian kualitatif. Karakteristik penelitian kualitatif, yaitu (1) pengumpulan data secara naratif dan visual, (2) seting latar belakang yang alami, (3) peneliti merupakan bagian dari penelitian, (4) analisis data dilakukan secara induktif, dan (5) peneliti menghindari pengambilan kesimpulan secara dini.

\section{Waktu dan Tempat Penelitian}

Penelitian ini dilaksanakan di Universitas Kuningan pada semester genap tahun ajaran 2015/2016.

\section{Subjek Penelitian}

Subyek dalam penelitian ini adalah mahasiswa semester dua prodi 
pendidikan matematika Universitas Kuningan tahun ajaran 2015/2016 yang terdiri dari 30 mahasiswa, dari 30 mahasiswa ini akan diambil 3 mahasiswa dengan rincian 1 mahasiswa berkemampuan tinggi, 1 mahasiswa berkemampuan sedang, dan 1 mahasiswa berkemampuan rendah.

\section{Prosedur Penelitian}

Langkah kerja yang dilakukan adalah meninjau masalah yang dihadapi di lapangan, mengumpulkan dan mengaitkan teori-teori, memberikan tes, melakukan wawancara, melakukan diagnosis hasil tes dan membuat kesimpulan.

\section{Data, Instrumen dan Teknik Pengumpulan Data}

Untuk memperoleh data yang berkaitan dengan objek yang sedang diteliti dan diharapkan dapat menunjang penelitian ini, peneliti melakukan pengumpulan data melalui pemberian tes visual-spatial thinking dan wawancara. Tes ini bertujuan untuk mendiagnosis kemampuan visual-spatial thinking mahasiswa. Tes terdiri atas Wawancara bertujuan untuk menggali informasi kesulitan mahasiswa secara mendalam, melalui wawancara akan memberikan kesempatan kepada mahasiswa untuk melakukan refleksi terhadap apa yang telah dikerjakan.

\section{Teknik Analisis Data}

Analisis data yang digunakan dalam penelitian ini adalah teknik analisis data kualitatif yaitu teknik triangulasi yang meliputi reduksi data (data reduction), penyajian data (data display), serta penarikan kesimpulan dan verifikasi (conclusion drawing and verification). 1) Proses reduksi data merupakan proses analisis data yang biasa berupa pemilihan, penyederhanaan, penggolongan, pemfokusan, serta transformasi data yang diperoleh. Semua data yang terkumpul dalam penelitian ini baik dari lembar soal tes, wawancara, maupun rekaman video selanjutnya direduksi sehingga dapat diperoleh suatu kesimpulan yang dapat diterima. 2) Penyajian data ini dilakukan dengan menyusun informasi-informasi secara berurutan supaya informasi yang diperoleh dapat digunkan sebagai sumber untuk menentukan suatu kesimpulan. Data yang sudah tersaji selanjutnya akan ditafsirkan serta dievaluasi untuk digunakan dalam proses selanjutnya. 3) Penarikan kesimpulan dilakukan setelah melakukan analisis data-data yang diperoleh serta menyesuaikan dengan dugaan-dugaan awal yang sudah diverifikasi. Untuk menetapkan keabsahan data maka diperlukan pengecekan keabsahan data. Dalam penelitian ini peneliti menggunakan triangulasi sumber. Teknik triangulasi sumber dilakukan dengan cara membandingkan data hasil tes dengan data hasil wawancara.

\section{Hasil Penelitian dan Pembahasan}

\section{Hasil Penelitian}

Berikut adalah hasil pekerjaan mahasiswa kemampuan tinggi (M1), mahasiswa kemampuan sedang (M2), dan mahasiswa kemampuan rendah (M3) dalam menjawab soal kemampuan Visual-Spatial Thinking. 


\section{Indikator 1 (mengubah informasi menjadi objek geometri)}

Soal : Diketahui kubus ABCD.EFGH dengan panjang rusuk $6 \mathrm{~cm}$.

a. Gambarlah ruas garis yang menyatakan jarak dari titik A ke HF. Berikan alasan atas jawabanmu itu.

b. Gambarlah ruas garis yang menyatakan jarak dari titik $\mathrm{C}$ ke bidang BDG. Kemudian tentukan nilainya. Berikan alasan atas jawabanmu itu.
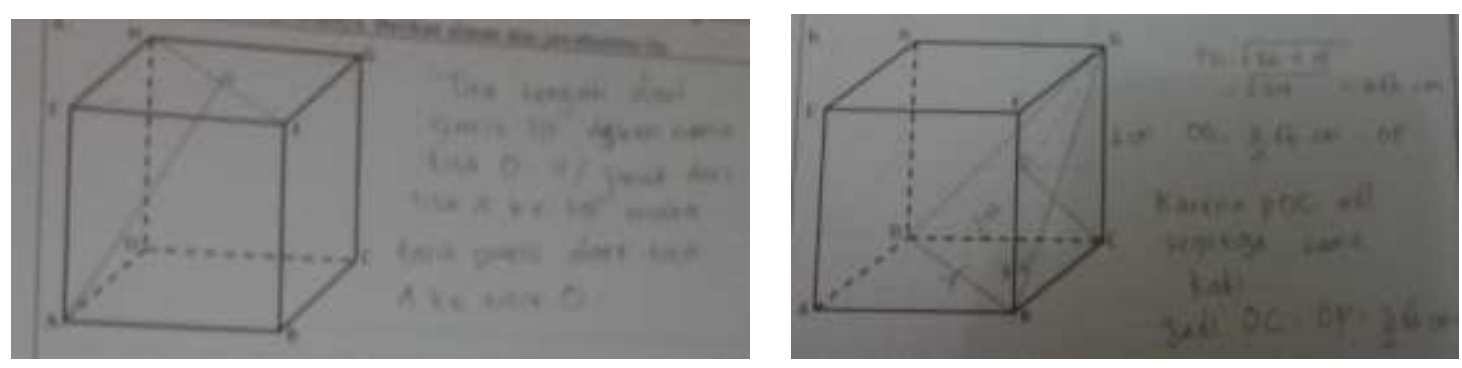

\section{Gambar 3. Hasil Kerja M1 untuk Indikator 1 Kemampuan Visual-Spatial} Thinking

M1 menggambar benar tetapi tidak memberikan tanda siku-siku yang menunjukkan bahwa garis AO tegak lurus Gasis HF. M1 juga tidak memberikan penjelasan AO tegak lurus HF pada jawaban yang M1 berikan.

Pada jawaban poin b. Juga jawaban M1 sudah benar tetapi kekurangan nya adalah informasi OC adalah jarak C ke bidang BDG (OC tegak lurus PG).
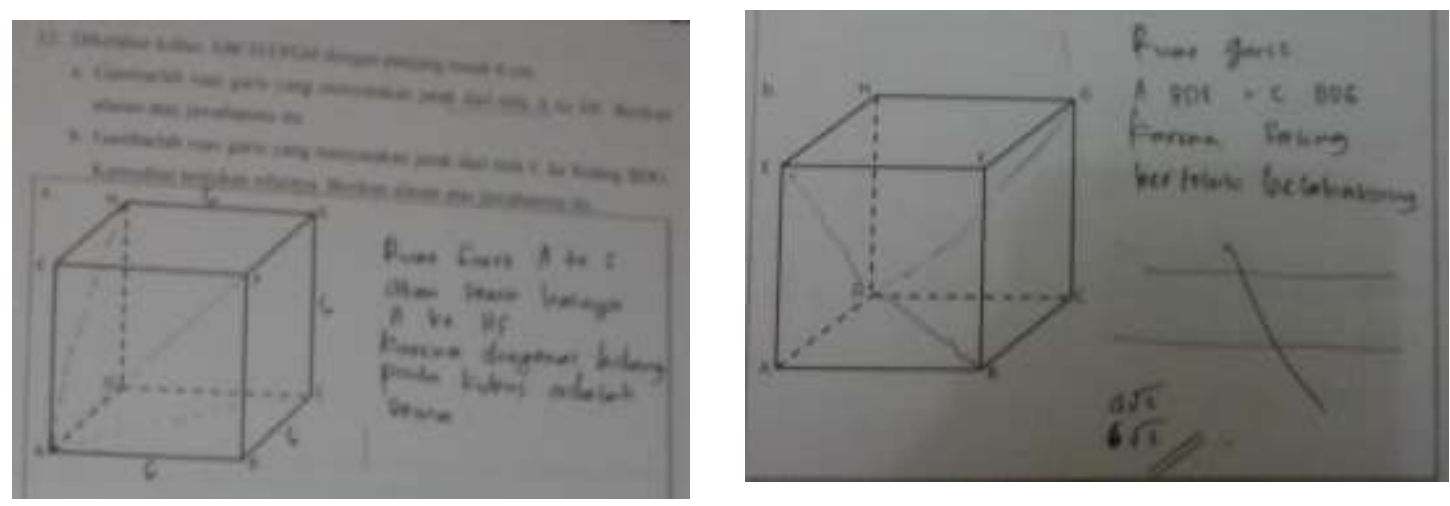

\section{Gambar 4. Hasil Kerja M2 untuk Indikator 1 Kemampuan Visual-Spatial Thinking}

M2 memberikan jawaban yang kurang tepat menggambarkan jarak A ke garis HF. terkait jarak A ke garis HF. Ia memberikan argumen bahwa ruas garis A ke C sama dengan A ke HF itu juga kurang tepat. Pada jawaban poin b. M2 salah dalam menggambarkan jarak ruas garis yang menyatakan jarak $\mathrm{C}$ ke bidang BDG. 

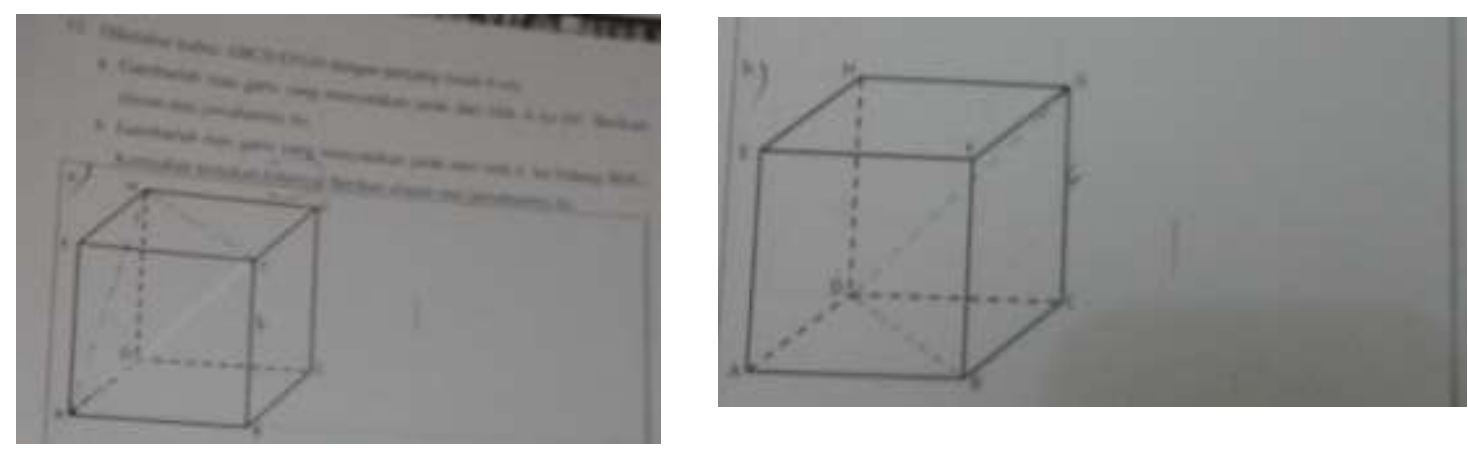

Gambar 5. Hasil Kerja M3 untuk Indikator 1 Kemampuan Visual-Spatial Thinking

Indikator 2 (membayangkan posisi suatu obyek geometri sesudah obyek tersebut mengalami rotasi, refleksi, atau dilatasi)
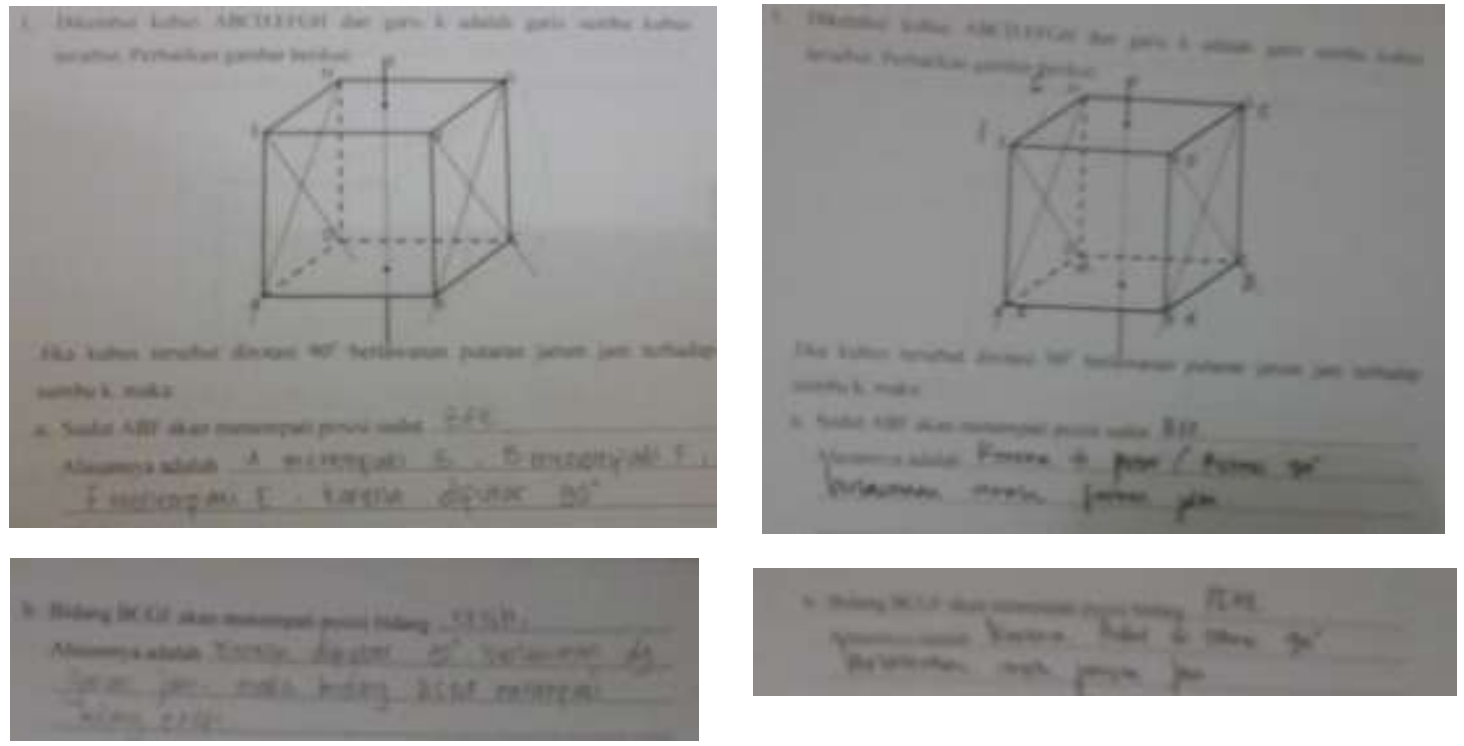

Gambar 6. Hasil Kerja M1 untuk Indikator 2 Kemampuan Visual-Spatial Thinking

Gambar 7. Hasil Kerja M2 untuk Indikator 2 Kemampuan VisualSpatial Thinking 


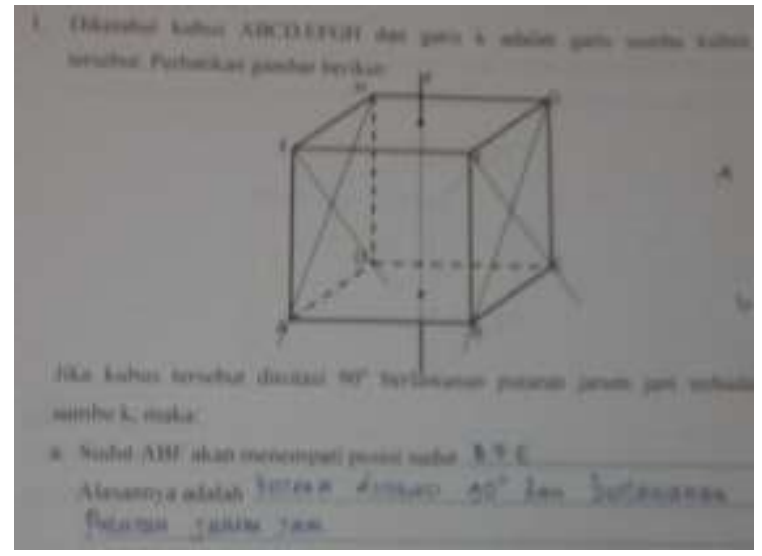

Baik M1, M2 maupun M3 memberikan jawaban yang benar tetapi memberikan alasan yang kuran tepat. Tidak memberikan alasan berdasarkan sifatsifat kubus yang bidang sisnya persegi dan memiliki sumbu simetri putar tingkat 4.

Gambar 8. Hasil Kerja M3 untuk

Indikator 2 Kemampuan Visual-Spatial

Thinking

Indikator 3. (membandingkan kaitan hubungan logis dari unsur-unsur suatu bangun ruang)

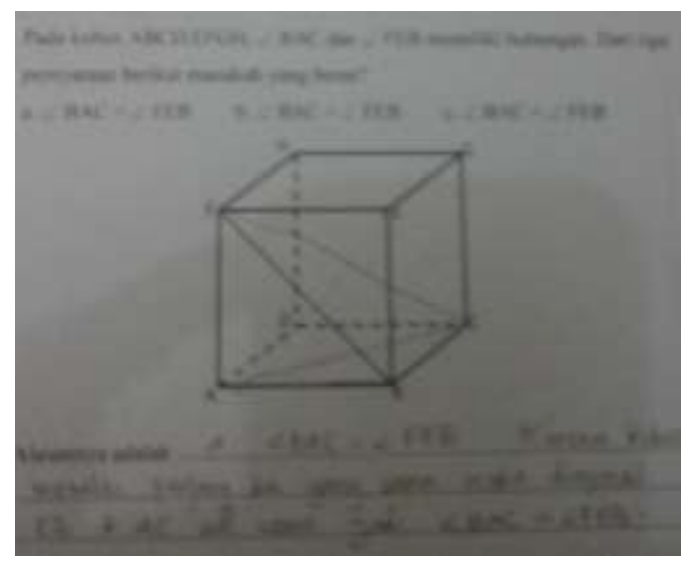

Gambar 9. Hasil Kerja M1 untuk Indikator 3 Kemampuan Visual-Spatial Thinking

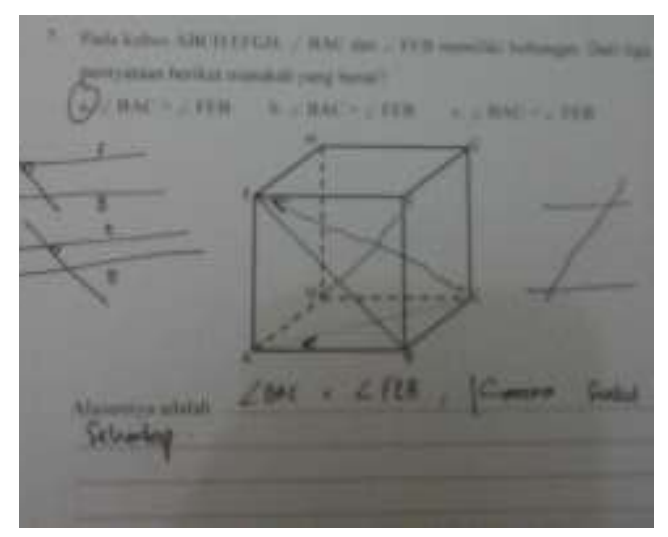

Gambar 10. Hasil Kerja M2 untuk Indikator 3 Kemampuan VisualSpatial Thinking 


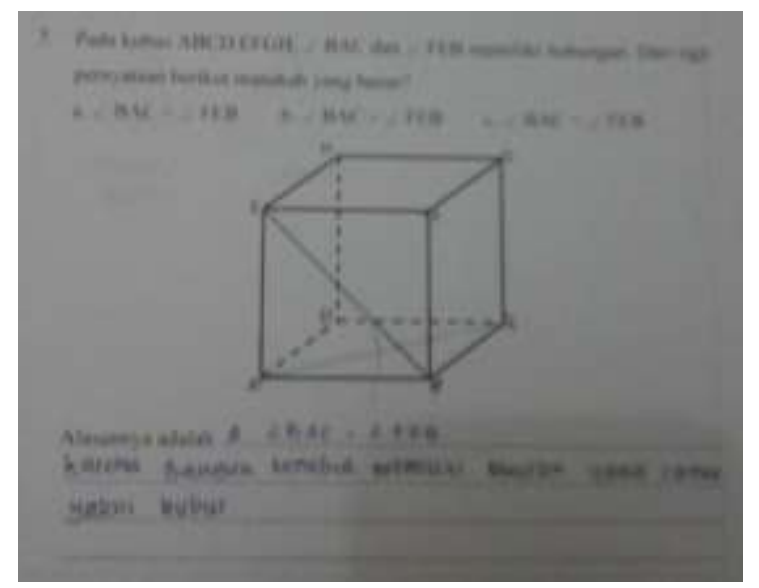

M1 menjawab dengan benar dan alasannya juga benar.

M2 menjawab dengan benar tetapi memberikan alasan salah

M3 menjawab dengan benar tetapi alasan salah

Gambar 11. Hasil Kerja M3 untuk Indikator 3 Kemampuan Visual-Spatial Thinking

Indikator 4. (menduga secara akurat bentuk suatu obyek dipandang dari sudut pandang tertentu)

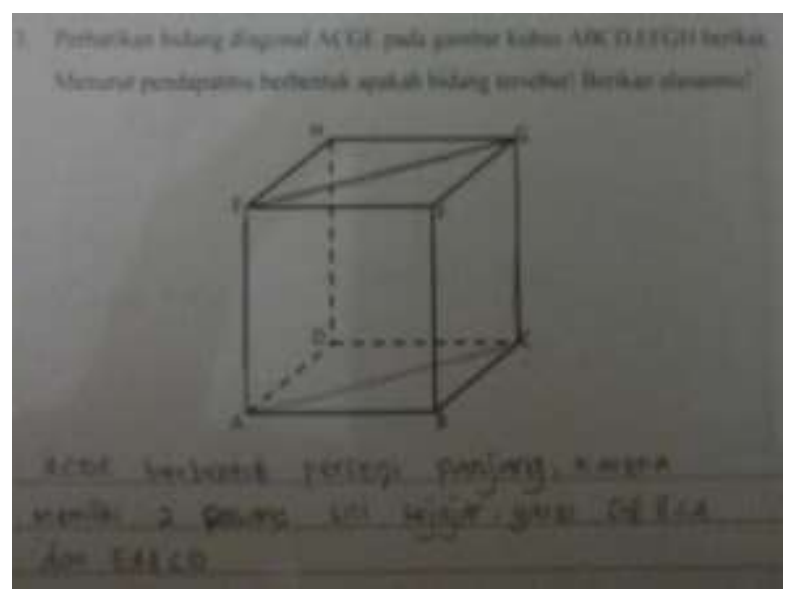

Gambar 12. Hasil Kerja M1 untuk Indikator 4 Kemampuan Visual-Spatial Thinking

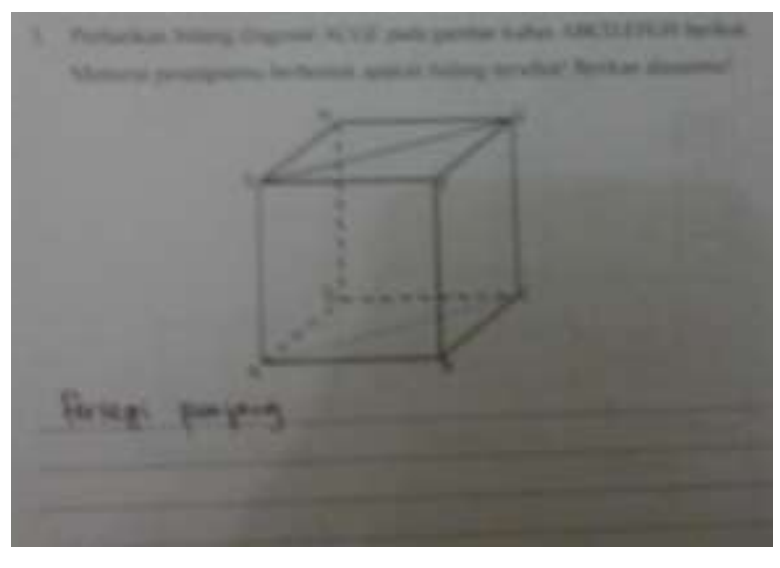

Gambar 13. Hasil Kerja M2 untuk Indikator 4 Kemampuan VisualSpatial Thinking 


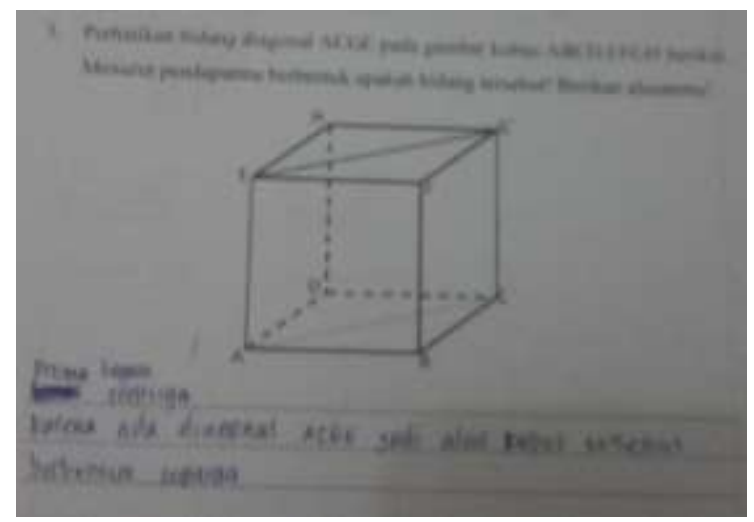

M1 menjawab dengan benar dan memberikan alasan dengan benar.

M2 menjawab dengan benar tetapi tidak memberikan alasan atas jawababnya

M3 memberikan jawaban yang salah, M3 cenderung tidak memahami makna dari bidang diagonal ACGE.

Gambar 14. Hasil Kerja M3 untuk

Indikator 4 Kemampuan Visual-Spatial

Thinking

Indikator 5. (menentukan obyek yang cocok pada posisi tertentu dari sederetan obyek bangun geometri ruang atau mengenal pola)

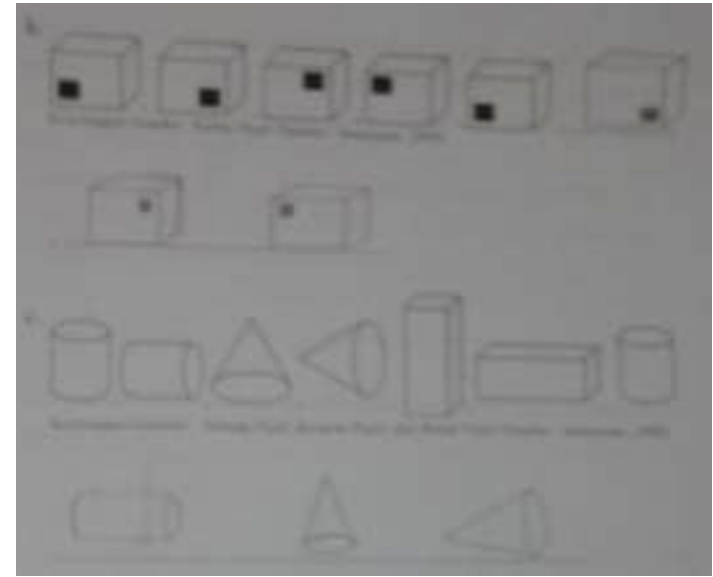

Gambar 15. Hasil Kerja M1 untuk Indikator 5 Kemampuan Visual-Spatial Thinking

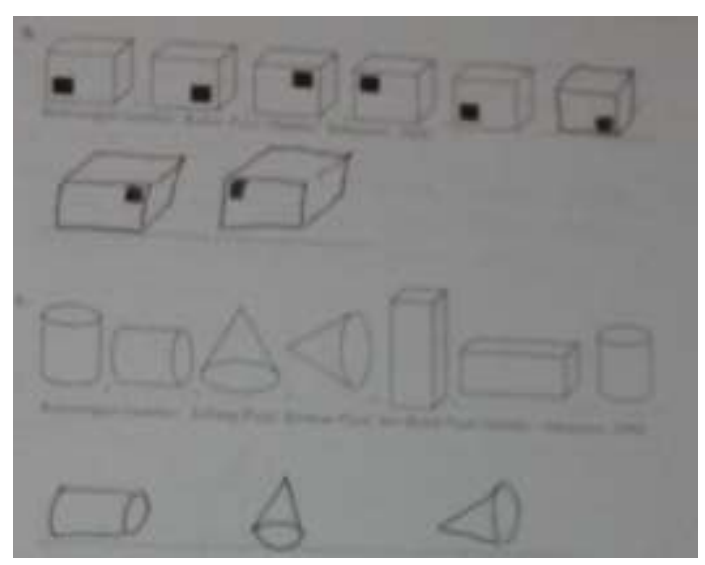

Gambar 16. Hasil Kerja M2 untuk Indikator 5 Kemampuan VisualSpatial Thinking 


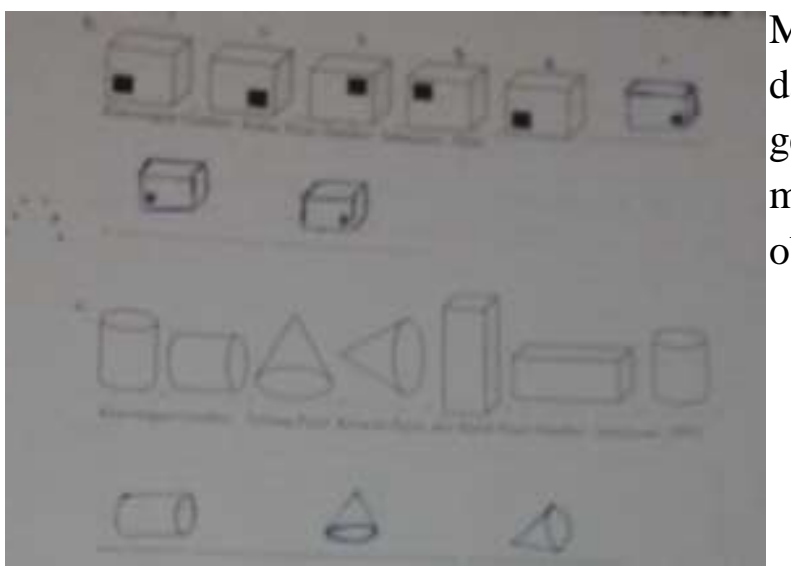

M1 dan M2 menjawab dengan benar dalam menentukan obyek / pola geometri, sedangkan M3 masih menjawab salah dalam menentukan obyek/pola geometri.

Gambar 17. Hasil Kerja M3 untuk

Indikator 5 Kemampuan Visual-Spatial

Thinking

Indikator 6. (merepresentasikan model-model bangun geometri yang digambarkan pada bidang datar)
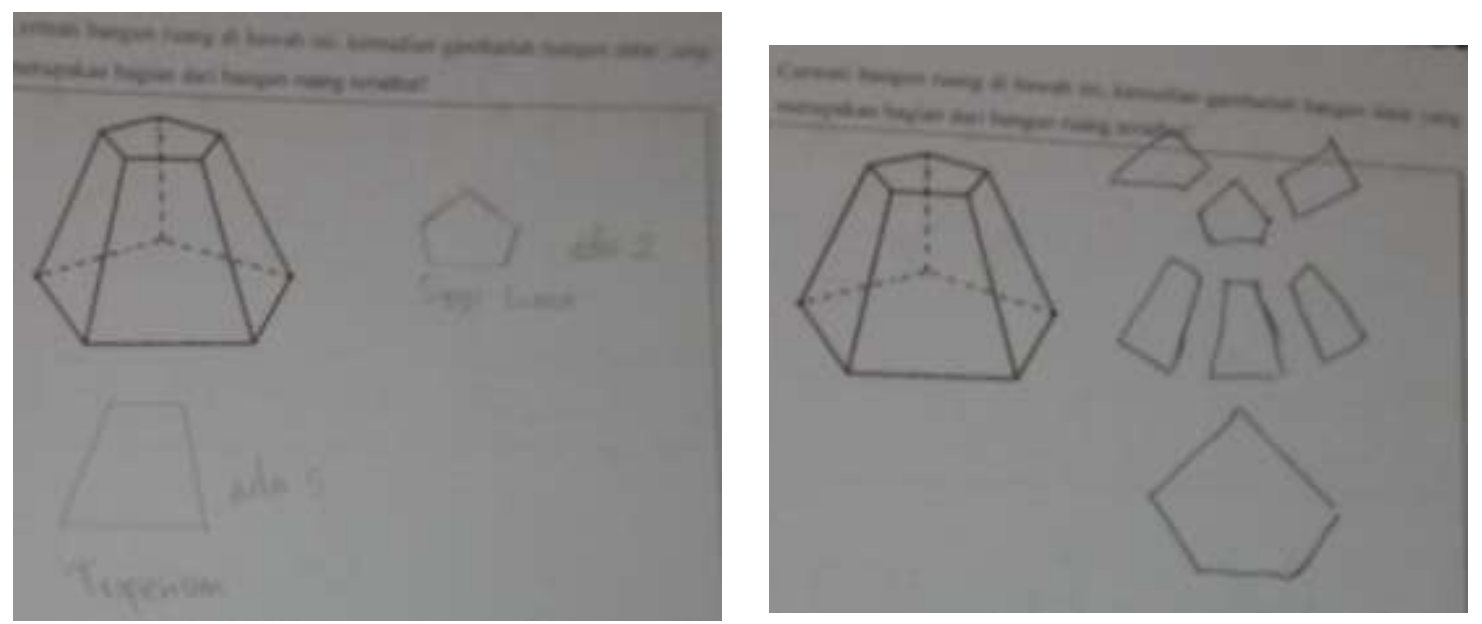

Gambar 18. Hasil Kerja M1 untuk Indikator 6 Kemampuan Visual-Spatial Thinking

Gambar 19. Hasil Kerja M2 untuk Indikator 6 Kemampuan VisualSpatial Thinking 


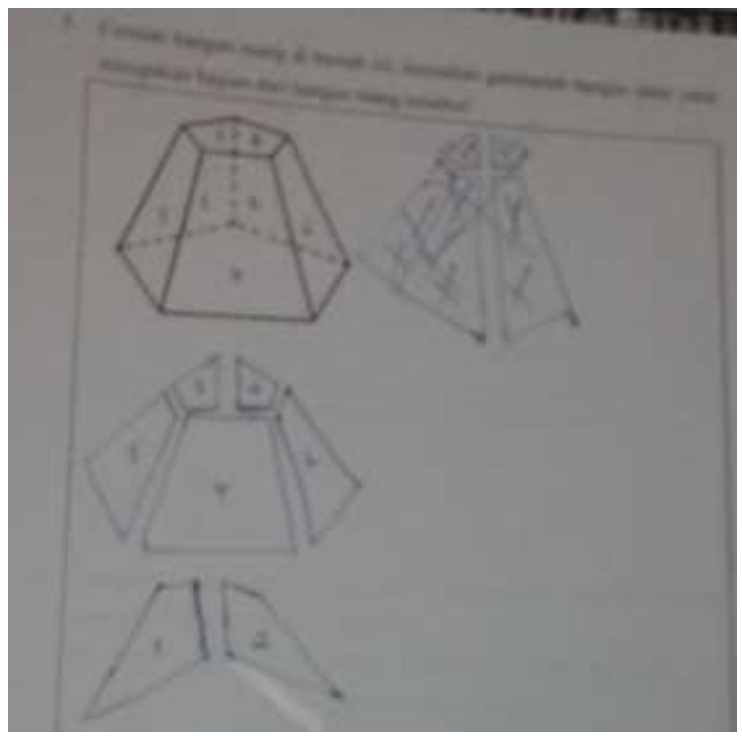

M1 menggambar sebagian dengan benar tetapi untuk bagian alas dan atas berbeda ukuran meskipun bentuknya sama.

M2 dan M3 menggambar semua tetapi bagian sisi tidak digambarkan dalam bentuk bidang dengan benar

Gambar 20. Hasil Kerja M3 untuk Indikator 6 Kemampuan Visual-Spatial Thinking

Indikator 7. (menemukan informasi dari visual berupa obyek sederhana dalam konteks keruangan yang kompleks)

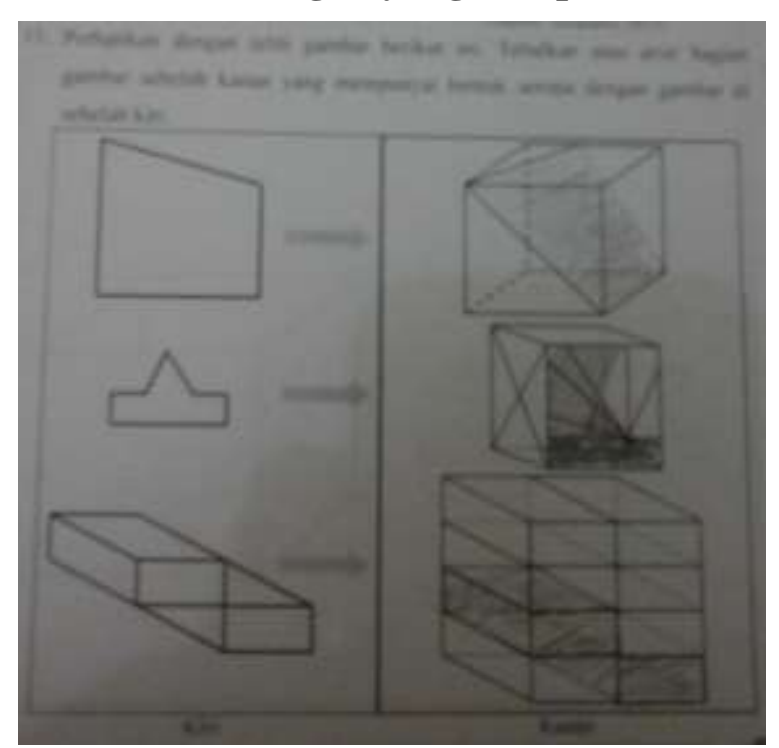

Gambar 21. Hasil Kerja M1 untuk Indikator 7 Kemampuan Visual-Spatial Thinking

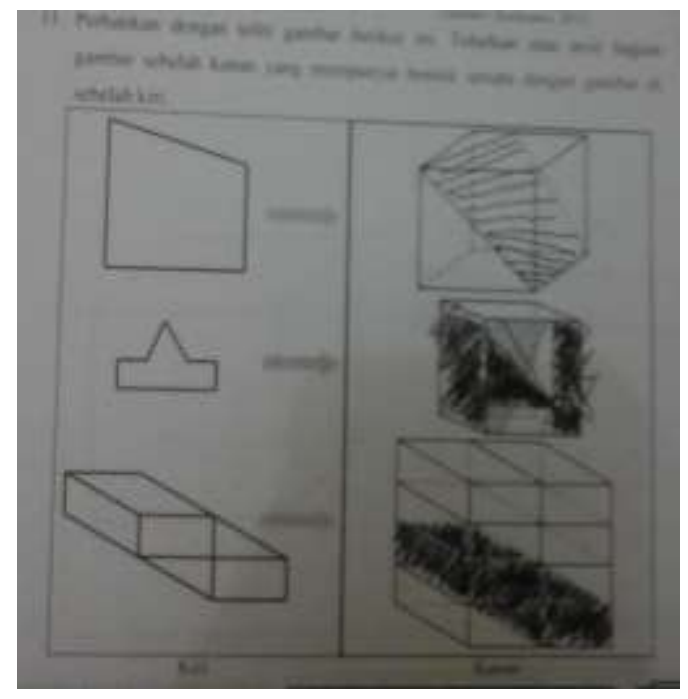

Gambar 22. Hasil Kerja M2 untuk Indikator 7 Kemampuan VisualSpatial Thinking 


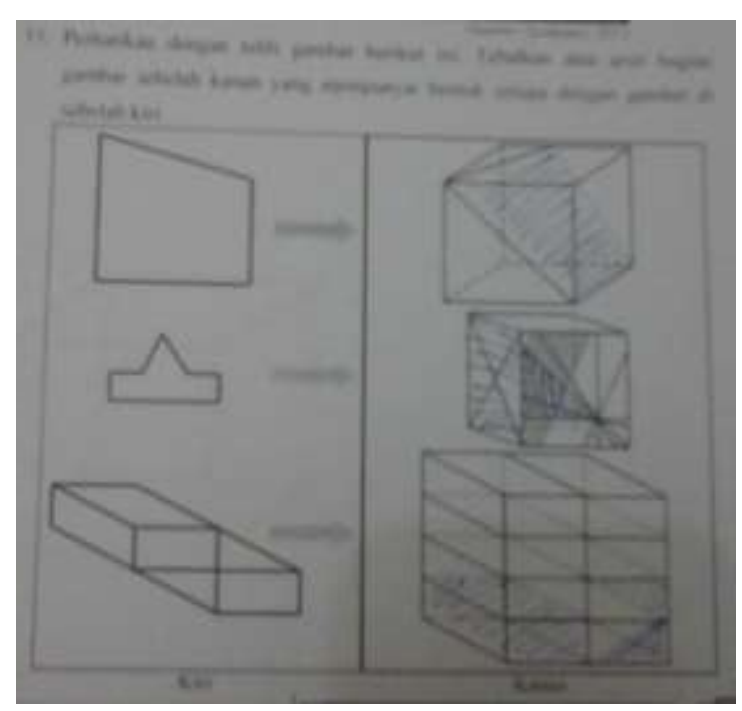

Gambar 23. Hasil Kerja M3 untuk Indikator 7 Kemampuan Visual-Spatial Thinking

\section{PEMBAHASAN}

Setelah peneliti menganalisis hasil pekerjaan M1, M2, dan M3 dalam mengerjakan soal kemampuan Visual-spatial thinking. Indikator 1 (mengubah informasi menjadi objek geometri) mahasiswa berkemampuan sedang (M2) dan rendah (M3) belum mampu mengubah informasi menjadi objek geometri dengan benar, sedangkan mahasiswa berkemampuan tinggi (M1) dapat mengubah informasi menjadi objek geometri dengan benar yaitu melalui menggambarkan ruas garis yang meyatakan jarak dari sebuat titik ke garis dan menggambarkan ruas garis yang menyatakan jarak dari sebuah titik ke bidang akan tetapi M1 tidak memberikan notasi tegak lurus. Hal tersebut menunjukkan bahwa M2 dan M3 belum memahami konsep garis tegak lurus dan proyeksi serta
M1 mengarsir tiga gambar dengan benar M2 mengarsir dua gambar dengan benar (gambar pertama dan ketiga)

sedangkan M3 mengarsir satu gambar dengan benar (gambar pertama)

konsep jarak titik, garis dan bidang dalam ruang dimensi tiga.

M1, M2 dan M3 mampu membayangkan posisi suatu obyek geometri sesudah obyek tersebut mengalami rotasi, akan tetapi mereka tidak memberikan jawaban untuk alasannya dengan benar. Mereka tidak memberikan alasan berdasarkan sifatsifat kubus yang bidang sisnya persegi dan memiliki sumbu simetri putar tingkat 4.

Indikator kemampuan visualspatial thinking ke-3 adalah membandingkan kaitan hubungan logis dari unsur-unsur suatu bangun ruang. M1, M2 dan M3 menjawab dengan benar tetapi memberikan alasan salah. Hal ini menunjukkan bahawa baik siswa berkemampuan tinggi, sedang maupun rendah belum memahami konsep sudut antara garis dan bidang.Dalam hal ini seharusnya 
alasan yang tepat adalah karena AC dan BE keduanya sama-sama diagonal bidang sisi kubus karena semua sudut pada bidang sisi kubus siku-siku maka AC dan BE sama-sama membagi sudut sama besar pada bidang sisi kubus.

Indikator kemampuan visualspatial thinking ke-4 adalah menduga secara akurat bentuk suatu obyek dipandang dari sudut pandang tertentu. M1 menjawab dengan benar dan memberikan alasan dengan benar. M2 menjawab dengan benar tetapi tidak memberikan alasan atas jawababnya. M3 memberikan jawaban yang salah, M3 cenderung tidak memahami makna dari bidang diagonal ACGE.

Indikator kemampuan visualspatial thinking ke-5 adalah menentukan obyek yang cocok pada posisi tertentu dari sederetan obyek bangun geometri ruang atau mengenal pola. M1 dan M2 menjawab dengan benar dalam menentukan obyek / pola geometri, sedangkan M3 masih menjawab salah dalam menentukan obyek/pola geometri. Berdasarkan hal tersbut M3 masih belum memiliki kemampuan dalam menentukan obyek yang cocok pada posisi tertentu dari sederetan obyek bangun geometri ruang/pola.

Indikator kemampuan visualspatial thinking ke-6 adalah merepresentasikan model-model bangun geometri yang digambarkan pada bidang datar. M1 menggambar sebagian dengan benar tetapi untuk bagian alas dan atas berbeda ukuran meskipun bentuknya sama dan untuk sisi-sisnya seharusnya digambarkan dengan lima buah bidang trapesium. M2 dan M3 menggambar semua tetapi bagian sisi tidak digambarkan dalam bentuk bidang dengan benar. Hal tersebut menunjukkan bahwa mahasiswa masih kurang dalam kemampuan merepresentasikan model-model bangun geometri yang digambarkan pada bidang datar

Indikator kemampuan visualspatial thinking ke-7 adalah menemukan informasi dari visual berupa obyek sederhana dalam konteks keruangan yang kompleks. M1 mengarsir tiga gambar dengan benar. M2 mengarsir dua gambar dengan benar (gambar pertama dan ketiga), sedangkan M3 mengarsir satu gambar dengan benar (gambar pertama). Hal tersebut menunjukkan bahwa M1 memiliki kemampuan menemukan informasi dari visual berupa obyek sederhana dalam konteks keruangan yang kompleks dibandingkan M2 dan M3.

Berdasarkan pemaparan di atas, dapat terlihat kemampuan visualspatial thinking mahasiswa terutama mahasiswa kemampuan sedang dan mahasiswa kemampuan rendah masih dalam kategori kurang. Terutama dalam konsep garis tegak lurus dan proyeksi; jarak titik, garis dan bidang; serta sudut antara garis dan bidang. Selama ini proses pembelajaran geometri ruang masih cenderung bersifat ekspository dan hanya di gambarkan dalam papan tulis (bidang dimensi dua), sehingga mahasiswa yang memiliki kemampuan spatial kurang baik kesulitan dalam memahami konsep geometri yang 
cenderung abstrak. Salah satu alternatif pembelajaran yang memfasilitasi agar mahasiswa membangun konsep pengetahuan sendiri adalah pembelajaran berbasis masalah (problem based learning). Sanjaya (2010) mendefinisikan bahwa PBL merupakan pendekatan pembelajaran yang mempunyai ciri menggunakan masalah nyata sebagai konteks bagi peserta didik untuk belajar berpikir kritis, keterampilan pemecahan masalah, dan memperoleh pengetahuan mengenai esensi materi pembelajaran. Sehingga peserta didik dituntut aktif menemukan konsepnya sendiri.

Seiring dengan perkembangan teknologi proses pembelajaran matematika terutama geometri yang dalam konsepnya lebih banyak konsep yang bersifat abstrak. Banyak software yang digunakan untuk membantu agar konsep geometri yang cenderung abstrak menjadi terlihat lebih nyata. Salah satu software yang memfasilitasi dalam pembelajaran geometri ruang adalah GeoGebra 5.0. GeoGebra 5.0 adalah salah satu perangkat lunak dinamis-geometri yang dapat digunakan untuk membantu peserta didik dan pendidik untuk mengatasi beberapa kesulitan dan membuat belajar geometri dimensi tiga (geometri ruang) menjadi lebih mudah dan menarik. Keunggulan yang dimiliki GeoGebra 5.0 adalah terdapat fasilitas/menu tampilan grafik 3D diperkirakan dapat meningkatkan hasil belajar peserta didik, yaitu dengan objek geometri pada GeoGebra 5.0 yang dapat diubah kedudukannya sehingga membantu peserta didik menentukan kedudukan objek geometri dalam ruang. Kemudian dengan adanya toolmeasurement pengguna dapat menentukan ukuran suatu sudut, panjang sisi, luas sisi, volume, dan lainnya. Dengan kata lain, pembelajaran geometri berbantuan GeoGebra 5.0 dapat membantu peserta didik untuk meningkatkan kemampuan visualspatial thinking peserta didik

\section{E. Kesimpulan dan Saran}

\section{Kesimpulan}

Berdasarkan pemaparan hasil pengerjaan soal kemampuan visualspatial thinking dan pembahasan maka dapat disimpulkan bahwa:

\section{a. Kemampuanvisual-spatial}

thinking mahasiswa masih rendah, terutama mahasiswa yang berkemampuan sedang dan rendah. Mahasiwa masih mengalami kesulitan dalam menyelesaikan soal yang berkaitan dengan konsep garis tegak lurus dan proyeksi; jarak titik, garis dan bidang; serta sudut antara garis dan bidang.

b. Kemampuan visual-spatial thinking merupakan kemampuan yang harus dikembangkan dalam belajar geometri ruang, salah satu penyebab rendahnya hasil belajar geometri ruang adalah karena kemampuan visual-spatial thinking yang masih rendah.

c. Salah satu upaya meningkatkan kemampuan visual-spatial thinking mahasiswa adalah pembelajaran geometri ruang melalui pembelajaran berbasis 
masalah dengan berbantuan software GeoGebra.

\section{Saran}

Berdasarkan pembahasan yang telah dipaparkan di atas maka penelitia memberikan saran sebagai berikut.

a. Perlu adanya bahan ajar yang memfasilitasi mahasiswa untuk mengembangkan kemampuan visual-spatial thinking.

b. Bahan ajar yang dikembangkan sebaiknya menggunakan model pembelajaran yang membuat mahasiswa mengonstruksi konsep geometri ruang dan menggunakan software yang dinamis agar konsep yang diajarkan menjadi tidak abstrak.

\section{Daftar Pustaka}

Abdussakir. (2009). Pembelajaran Geometri dan Teori Van Hiele. [Online].

Tersedia:http://abdusakir.wordpr ess.com/2009/01/25/pembelajara ngeometri-danteorivan-hiele/[10 Oktober 2013].

Black, A. A. (2005). Spatial Ability and Earth Science Conceptual Understanding. Springfield: Missouri State University. [Online]. Tersedia: http://www.redorbit.com/news/scie nce/268601/spatial ability and ear th_science_conceptual_understandi ng/ [25 Oktober 2013].

Bolton, S. (2011). Decoding Visual Thinking. Naver Workshop, Visualising Creative Strategies. [Online].

Tersedia: http://issuu.com/gpbr/docs/decodin gvisualthinking. [2 Januari 2013].
Dwirahayu, G. (2013). Pengaruh Strategi Pembelajaran Eksploratif terhadap Peningkatan kemampuan Visualisai, Pemahaman Konsep Geometri, dan Karakter Siswa. Disertasi Jurusan Pendidikan Matematika SPsUPI Bandung. Tidak diterbitkan.

Giaquinto, M. (2007). Visual Thinking in Mathematics An Epistemological Study. United States: Oxford University Press Inc., New York.

Gumilar. (2012). Pembelajaran Geometri dengan Wingeom untuk Meningkatkan Kemampuan Spasial dan Penalaran Matematis Siswa. Tesis pada SPs UPI. Tidak diterbitkan.

Ismi, I. N. \& Hidayatulloh, B. (2012). Pentingnya Visual Thinking dalam Pembelajaran Geometri SMP. [Online]. Tersedia: http://ohmymath.wordpress.com/cat egory/jurnal-dan-artikel/ Oktober 2013].

Kariadinata, R. (2010). Aplikasi Berbasis Komputer dalam PembelajaranMatematika.

Disertasi Jurusan Pendidikan Matematika SPs UPI Bandung. Tidak diterbitkan.

Mohler, J. L. (2010). The VisualSpatial System: Cognition \& Perception. Purdue University. [Online].

Tersedia: http://www.hpcg.purdue.edu/bbene s/classes/CGT5818/lectures/CGT\%20581-8-05Perc2.pdf[25 Oktober 2013]. 
National Academy of Science (2006).

Learning to Think Spatially. Washington DC: The National Academics Press.

Nemeth, B. (2007). Measurement of the Development of Spatial Ability by Mental Cutting Test. Annales Mathematicae et Informaticae 34 pp. 123-128. Tersedia:

http://www.ektf.hu/tanszek/matema tika/ami [10 Januari 2013].

Risnawati. (2012). Pengaruh Pembelajaran dengan Pendekatan Induktif-Deduktif Berbantuan Program Cabri Geometry terhadap Peningkatan Kemampuan Representasi Matematis Siswa Sekolah Menengah Pertama. Tesis SPs UPI. Bandung. Tidak Diterbitkan.

Sanjaya, W. (2010). Strategi Pembelajarran Berorientasi Standar Proses Pendidikan. Jakarta: Kencana Prenada Media Group.
Schwartz, J.E. (2010). Why Learn Geometry? [Online] Update on Jul 20, 2010. Tersedia: http://www.education.com/referenc e/article/why-learn-geometrymathematics/ [3 Juni 2014].

Surya, E. (2011). Visual Thinking dalam Memaksimalkan Pembelajaran Matematika Siswa dapat Membangun Karakter Bangsa. Jurusan Pendidikan Matematika FPMIPA Unimed.

Sword, L. K. (2005). The Power of Visual Thinking. [Online]. Tersedia: http://www.tempinformationsheets. apduk.org.uk/HTMLobj210/Power_of_Visual_Thinking.pd f [20 Oktober 2013].

Zhukovskiy, V. I \& Pivovarov, D. V. (2008). The Nature of Visual Thinking. Journal of Serbian Federal University. [Online]. Tersedia:http://journal.sfukras.ru/en/article/641/25 
